\title{
IMPLEMENTASI MANAJEMEN PEMBELAJARAN KARAKTER BERBASIS TOTAL QUALITY MANAGEMENT DI SMP MUHAMMADIYAH 3 YOGYAKARTA
}

\author{
Yoga Anjas Pratama \\ Magister FITK UIN Sunan Kalijaga Yogyakarta \\ Email: yogaanjasp8@gmail.com
}

\begin{abstract}
Abstrak
Pembelajaran karakter berbasis Total Quality Management merupakan proses pentransferan, pembiasaan, dan pembentukan nilai-nilai karakter oleh pendidik terhadap peserta didik, yang dilakukan berdasarkan konsep Total Quality Management, yaitu: quality, kepuasan pelanggan, perbaikan terus menerus, dan menyeluruh disemua komponen organisasi. Penelitian ini merupakan penelitian lapangan yang bersifat kualitatif deskriptif yang dilatar belakangi oleh tingginya tingkat kenakalan remaja atau penyimpangan moral akibat dari kurangnya penanaman nilai-nilai karakter pada diri peserta didik. Oleh sebab itu dalam penelitian ini penulis mengambil lokasi penelitian di SMP Muhammadiyah 3 Yogyakarta, yang menerapkan pembelajaran karakter berbasis Total Quality Management. Dari penelitian yang dilakukan ditemukan hal-hal sebagai berikut: (1) SMP Muhammadiyah 3 Yogyakarta telah menanamkan dan menerapkan nilai-nilai karakter (religius, nasionalis, intergritas, mandiri, dan gotong royong) melalui kegiatan-kegiatan sekolah (2) SMP Muhammadiyah 3 Yogyakarta telah mengimplementasikan konsep Total Quality Management dalam pembelajaran karakter (3) SMP Muhammadiyah 3 Yogyakarta telah menerapkan kurikulum 2013 dalam proses pembelajaran karakter berbasis Total Quality Management yang disesuaikan dengan langkah-langkah pembelajaran, meskipun pada dasarnya masih banyak yang membutuhkan upaya perbaikan secara terus menerus.
\end{abstract}

Kata kunci: Pembelajaran Karakter, Total Quality Management.

\begin{abstract}
Character learning based on Total Quality Management is the process, transfer, habituation, and formation of character values by educators to students, which are carried out based on the total quality management concept, namely: quality, customer satisfaction, continuous improvement, and overall in all organizational components. This research is a qualitative descriptive field research which is background by the high level of juvenile delinquency or moral deviation as a result of the lack cultivation of character values in students. Therefore, in this study the author took the location of research at Mubammadiyah 3 Middle School in Yogyakarta, who apply total quality management based character learning. From the research carried out found things, as follows: (1) Muhammadiyah 3 Middle School Yogyakarta has instilled and applied character values (religious, nationalist, independent, and mutual cooperation) through school activities (2) Mubammadiyah 3 Middle School Yogyakarta has implemented the concept of Total Quality Management in character learning (3)
\end{abstract}

Nidhomul Haq: Jurnal Manajemen Pendidikan Islam

ISSN: 2503-1481 Hal: 1-22

DOI: $10.31538 /$ ndh.v4i1.184 
Muhammadiyah Middle School 3 Yogyakarta has implemented the 2013 curriculum in the character learning process based on Total Quality Management, which is adjusted to the learning steps, although basically there are still many who need continuous improvement efforts.

Keyword: Character Learning, Total Quality Management.

\section{A. PENDAHULUAN}

Pendidikan karakter merupakan berbagai usaha yang dilakukan oleh berbagai personil sekolah, bersama-sama dengan orang tua dan anggota masyarakat untuk membantu anak-anak atau remaja agar menjadi atau memiliki sifat peduli, berpendirian dan bertaggung jawab. ${ }^{1}$

Pendidikan karakter bukan lah hal yang baru dalam dunia pendidikan di Indonesia karena sejak dahulu banyak sekali bentuk perhatian pemerintah terhadap pendidikan karakter sebagai contoh: UUD 1946 yang berlaku pada tahun 1947, UU Sisdiknas Nomor 20 Tahun 2003, dan PERPRES Nomor 87 Tahun 2017.

Dikutip Marzuki dari Thomas Lickona bahwa pendidikan karakter bertujuan untuk membawa peserta didik mengenal nilai secara kognitif, penghayatan nilai secara afektif, dan akhirnya kepada pengenalan secara nyata. ${ }^{2}$

\footnotetext{
1 Evinna Cinda Hendriana en Arnold Jacobus, "Implementasi Pendidikan Karakter di Sekolah Melalui Keteladanan dan Pembahasan", Jurnal Pendidikan Dasar Indonesia, Vol. 1, No. 2, 2016, hlm. 26.

2 Marzuki, "Pengintergrasian Pendidikan Karakter dalam Pembelajaran di Sekolah", Jurnal Pendidikan Karakter, Vol. II, No. 1, 2012, hlm. 34.
}

Saat ini banyak sekali dijumpai masalah-masalah dikalangan peserta didik terkait dengan berbagai bentuk kenakalan remaja seperti: tawuran antar pelajar, bullying, minum-minuman keras, hingga berhubungan seksual dengan lawan jenis ffree sex).

Dikutip Siti Julaiha dari Sex Behaviors Survey di lima kota besar di Indonesia yaitu: Jabotabek, Bandung, Yogyakarta, Surabaya dan Bali pada bulan Mei 2011, menyatakan bahwa dari 663 responden yang diwawancarai mengakui bahwa 39\% responden remaja usia antara 15-19 tahun pernah melakukan hubungan seksual, dan sisanya $61 \%$ berusia $20-25$ Tahun. $^{3}$

Berdasarkan penjelasan diatas diketahui bahwa masih tingginya tingkat kenakalan remaja atau penyimpangan moral yang seharusnya dapat ditangani dan dicegah terlebih dahulu melalui pendidikan disekolah atau pembelajaran dikelas.

Pembelajaran dikelas merupakan lahan subur dalam penyaluran nilai-nilai keagamaan, kehidupan, dan sosial, yang

3 Siti Zulaikha, "Implementasi Pendidikan Karakter dalam Pembelajaran", Jurnal Dinamika Ilmu, Vol. 14, No. 2, 2014, hlm. 227. 
nantinya diharapkan dari pembelajaran yang dilakukan dapat membentuk karakter peserta didik yang Islami dan mampu membentengi diri dari nilai-nilai yang menyimpang dan dapat merusak karakter diri.

Kementerian Pendidikan dan Kebudayaan mencangankan empat nilai karakter dikalangan peserta didik yang didasari oleh filosofi $\mathrm{Ki}$ Hajar Dewantara yaitu: olah hati (etika), olah pikir (literasi), olah karsa (estitika), dan olah raga (kinestetik). ${ }^{4}$ Nilai-nilai tersebut diharapkan dapat di intergrasikan dalam bentuk pembelajaran disekolah sebagai bentuk dari penerapan pendidikan yang berkarakter.

Pembelajaran karakter sebenarnya sudah dilaksanakan sejak dahulu, hanya saja dalam penerapanya dibutuhkan waktu dan usaha yang sungguh-sungguh, baik dari kepala sekolah, guru, peserta didik, dan semua elemen yang terlibat. Usaha yang sungguh-sungguh ini berkaitan langsung dengan perbaikan yang berkelanjutan (total quality management) sebagai pendekatan manajemen dalam mensukesekan pembelajaran yang berkarakter.

Total Quality Management sebagai suatu pendekatan diharapkan mampu mewujudkan ketercapaian dari pembelajaran karakter, yaitu dengan fokus pada kepuasan pelanggan, quality, keterlibatan total,

${ }^{4}$ https://indonesiabaik.id/infografiskegiatan-pendidikan-karakter.html diakses pada 22 November 2018 komitmen, dan perbaikan yang berkelanjutan.

SMP Muhammadiyah 3 Yogyakarta merupakan sebuah lembaga pendidikan menegah atas milik Muhammadiyah yang telah menerapkan lima hari pembelajaran dan memiliki visi untuk "terwujudnya siswa beriman, unggul dalam prestasi dan berwawasan lingkungan" hal ini diwujudkan pihak sekolah dalam berbagai macam bentuk kegiatan sekolah yang dilakukan, seperti: kegiatan tadarus dipagi hari, sholat dhuha, dzuhur, ashar, pembinaan membaca alquran, hafalan jus 30 dan lain sebagainya. Kegiatankegiatan yang dilakukan tersebut merupakan salah satu cara yang dilakukan SMP Muhammadiyah 3 Yogayakarta untuk membentuk karakter peserta didik yang beriman, unggul dan berprestasi.

Dari pemaparan diatas penulis tertarik untuk mengkaji lebih medalam mengenai pembelajaran karakter berbasis Total Quality Management yang dalam hal ini penulis tuangkan dalam bentuk penelitian dengan judul "Implementasi Pembelajaran Karakter Berbasis Total Quality Management di SMP Muhammadiyah 3 Yogyakarta”. Penelitian ini dimaksudkan untuk mengetahui konsep dan implementasi penerapan pembelajaran karakter berbasis Total Quality Management di SMP Muhammadiyah 3 Yogyakarta sehingga kedepanya dapat dijadikan salah satu rujukan 
dalam pembelajaran karakter berbasis Total

Quality Management.

\section{B. KAJIAN TEORI}

1. Pengertian dan Konsep Pembelajaran Karakter

Menurut Zubaedi pendidikan karakter merupakan sebuah pendidikan budi pekerti plus yang bertujuan untuk mengembangkan watak dan tabiat peserta didik dengan cara menghayati nilai-nilai dan keyakinan masyarakat sebagai kekuatan moral dalam hidupnya yang dilakukan melalui kejujuran, kepercayaan, kedisiplinan, dan kerja sama yang menekankan pada ranah afektif, kongnitif, dan skill. ${ }^{5}$

Pendidikan karakter dalam penerapanya dilingkungan sekolah dapat diterapkan dalam bentuk pembelajaranpembelajaran dikelas yang berupa pembiasaan pembangunan karakter melalui keteladanan atau penanaman nilai karakter kepada peserta didik.

UUD Sisdiknas No. 20 Tahun 2003 menegaskan bahwa pembelajaran merupakan suatu proses interaksi antara peserta didik dengan pendidik dan sumber belajar pada suatu lingkungan

5 Moh Haitami Salim, Pendidikan Karakter: Konsepsi dan Implementasinya Secara Terpadu di Lingkungan Keluarga, Sekolah, Perguruan Tinggi, dan Masyarakat, (Yogyakarta: AR-RUZZ MEDIA, 2016), hlm. 30-31. belajar. $^{6}$ Dengan demikian maka pembelajaran karakter dapat dipahami sebagai proses pentransferan, pembiasaan, atau pembentukan nilainilai karakter yang dilakukan oleh pendidik terhadap peserta didik dalam suatu lingkungan belajar.

Pembelajaran karakter pada dasarnya merupakan pengintergrasian nilai-nilai agama kedalam pembelajaran ${ }^{7}$ yang dimaksudkan agar nilai-nilai agama tersebut dapat menjadi pedoman dan arahan peserta didik dalam rutinitas kehidupan sehari-hari. Berikut hadis Rasulullah Saw:

Artinya: Ingatlah bahwa anak cucu Adam tercipta atas enam tingkatan, yaitu: (1) Dilahirkan dalam keadaan mukmin, hidup sebagai seorang mukmin, dan matinya sebagai seorang mukmin pula, (2) Dilahirkan dalam keadaan kafir, hidup sebagai seorang kafir, dan matinya pun menjadi kafir (3) Dilahirkan sebagai seorang mukmin dan hidup sebagai seorang mukmin, tetapi matinya sebagai orang kafir (4) Dilahirkan sebagai orang kafir, dan hidupnya menjadi orang kafir, tetapi matinya sebagai seorang mukmin (5) Baik ketetapan hidupnya, dan (6) baik mata pencarianya. (HR. Abu Sa'id alKhudry). ${ }^{8}$
6 Evinna Cinda Hendriana en Arnold Jacobus, "Implementasi Pendidikan Karakter, ..., hlm. 26. Karakter, ..., hlm. 231.

7 Siti Zulaikha, "Implementasi Pendidikan

${ }^{8}$ Heri Gunawan, Pendidikan Karakter: Konsep dan Implementasi, (Bandung: Alfabeta, 2012), hlm. 51. 


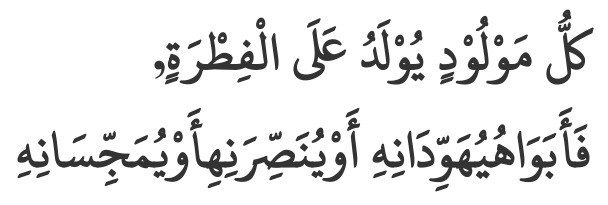

Artinya: Setiap anak dilahirkan dalam keadaan fitrah, maka kedua ayah dan ibunyalah yang menjadikannya Yahudi, Nasrani atau Majusi. (HR. Bukhari dan Muslim). ${ }^{9}$

Dari hadits diatas dapat dipahami bahwa setiap anak yang dilahirkan, pasti dalam keadaan suci (fitrah) dan tidak mengerti apa-apa, namun untuk menjadikanya seorang mukmin, hidup dan mati sebagai seorang mukmin, dibutuhkan penanaman pendidikan keagamaan (karater) sejak dini dan dilakukan secara terus menerus.

Ahmad Tafsir mengatakan bahwa proses pengintergrasian pendidikan agama ke dalam pembelajaran dapat dilakukan dengan langkah-langkah, sebagai berikut: (1) pengintergrasian materi pelajaran (2) pengintergrasian proses pengintergrasian pemilihan bahan ajar, dan (4) pengintergrasian pemilihan media. ${ }^{10}$ Sementara itu Ratna Megawangi menyebutkan sembilan karakter penting yang harus ditanamkan pada diri anak, sebagai berikut: (1) Mulai dari cinta

${ }^{9}$ http:/ / kumpulanmakalahkuliahlengkap.blo gspot.com/2017/03/konsep-fitrah-manusia.html diakses pada 15 November 2018

10 Ahmad Tafsir, Pendidikan Budi Pekerti, (Bandung: Maestro, 2009), hlm. 85.
Tuhan dan alam semesta beserta isinya (2) Tanggung jawab, kedisiplinan, dan kemandirian (3) Kejujuran (4) Hormat dan santun (5) Kasih sayang, kepedulian dan kerja sama (6) Percaya diri, kreatif, kerja keras, dan pantang menyerah (7) Keadilan dan kepemimpinan (8) Baik dan rendah hati (9) Toleransi, cinta damai, dan persatuan. ${ }^{11}$

Dikutip dari Permendikbud RI No. 20 Tahun 2018 tentang Penguatan Pendidikan Karakter Pada Satuan Pendidikan Formal, bahwa pada pasal 2 ayat (1) dijelaskan bahwa pelaksanakan PPK dilakukan dengan menerapkan nilai-nilai Pancasila dalam pendidikan karakter yang meliputi nilai-nilai relegius, jujur, toleran, disiplin, bekerja keras, kreatif, mandiri, demokratis, rasa ingin tahu, semangat kebangsaan, cinta tanah air, menghargai prestasi, komunikatif, cinta damai, gemar membaca, peduli lingkungan, peduli sosial, dan bertanggung jawab. Sedangkan pada pasal 2 ayat (2) dijelaskan bahwa nilai sebagaimana dimaksud pada ayat (1) merupakan perwujudan dari 5 (lima) nilai utama yang saling berkaitan, yaitu: relegiusitas, nasionalisme, kemandirian, gotong royong, dan intergritas yang terintergrasi dalam kurikulum. ${ }^{12}$

11 Ratna Megawangi, Pendidikan Karakter Solusi yang Tepat untuk Membangun Bangsa, (Bogor: Indonesia Heritage Foundation, 2007), hlm. 72.

12 Peraturan Menteri Pendidikan dan Kebudayaan Republik Indonesia Nomor 20 Tahun 
2. Penerapan Total Quality Management dalam Pembelajaran Karakter

Total Quality Management (TQM) merupakan suatu sistem manajemen yang difokuskan kepada seseorang/tenaga kerja, dengan tujuan untuk dapat terus meningkatkan nilai (value) yang diberikan kepada pelanggan, dengan biaya penciptaan nilai yang lebih rendah dibandingkan nilai tersebut. ${ }^{13}$

Selain itu dikutip oleh Bismar Harris Satriawan dari Khim dan Larry bahwa Total Quality Management ialah merupakan konsep yang menekankan kepada peningkatan dari proses pemanufakturan secara berkelanjutan dengan meningkatkan kualitas, mengeliminasi pemborosan, mengembangkan keterampilan dan mengurangi biaya produksi. ${ }^{14}$

Berdasarkan pengertian diatas, maka Total Quality Management dalam pembelajaran karakter dapat dipahami sebagai suatu pendekatan yang digunakan untuk memaksimalkan kinerja, tenaga kerja, mutu, produk, dan lingkungan untuk ketercapaian dari tujuan pembelajaran karakter dengan

2018 tentang Penguatan Pendidikan Karakter, hlm. 34

13 Achmad Supriyanto, "Implementasi Total Quality Management dalam Sistem Manajemen Mutu Pembelajaran di Institusi Pendidikan", FIP Universitas Malang, hlm. 17.

14 Bismar Harris Satriawan, Total Quality Management (TQM): Analisis Akar Masalah Penerapan Teknologi Informasi dan Komunikasi (TIK) di Kabupaten Purbalingga, (Yogyakarta: Tata Kelola Sektor Publik MIP-UMY), hlm. 4. upaya perbaikan secara terus menerus dan berkelanjutan.

Total Quality Management memiliki beberapa konsep, yaitu: (1) Quality (2) Kepuasan pelanggan (3) Perbaikan terus-menerus, dan (4) menyeluruh disemua komponen organisasi. $^{15}$ Dalam pembelajaran karakter beberapa konsep ini dapat dijelaskan, sebagai berikut:

a. Quality. Quality atau kualitas yang dimaksud ialah berupa output atau outcome setelah dilakukanya pembelajaran karakter atau penanaman nilai-nilai karakter pada peserta didik melalui pembelajaran. Output atau outcome yang dimaksud ialah peserta didik mengimplementasikan nilai-nilai karakter yang diperoleh dalam pembelajaran di kehidupan seharihari. Berikut lima nilai karakter yang dimaksud, yang dikutip dari Gerakan Penguatan Pendidikan Karakter (PPK) Kementerian Pendidikan dan Kebudayaan Republik Indonesia: ${ }^{16}$

15 Aminatul Zahroh, Total Quality Management: Teori dan Prakttik Manajemen untuk Mendongkrak Mutu Pendidikan, (Yogyakarta: ARRUZZ Media, 2016), hlm. 93.

16 Kementerian Pendidikan dan Kebudayaan Republik Indonesia, Gerakan Penguatan Pendidikan Karakter (PPK), cerdasberkarakter.kemendikbud.go.id diakses pada 22 November 2018 


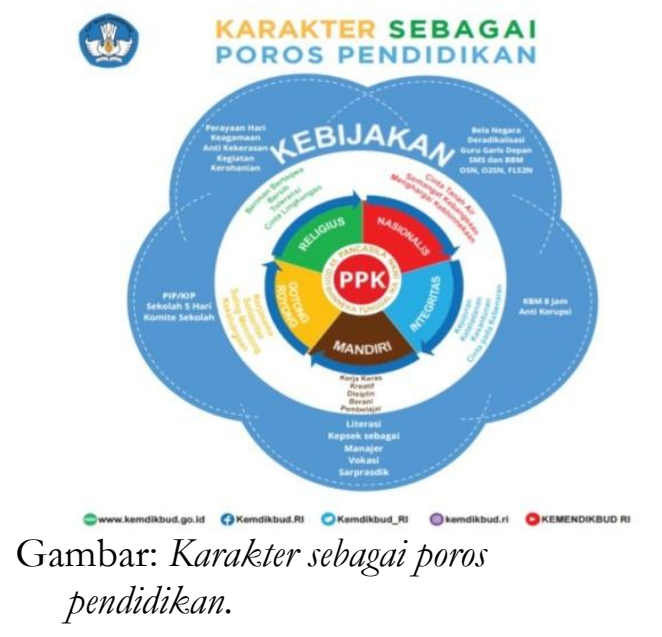

Berdasarkan gambar diatas, terdapat lima nilai dalam Penguatan Pendidikan Karakter (PPK), yaitu: (1) Relegius, ialah nilai yang mencerminkan keberimanaan terhadap Tuhan YME, meliputi: beriman, bertaqwa, bersih, toleransi dan cinta lingkungan. (2) Nasionalis, ialah nilai yang menempatkan kepentingan bangsa dan negara diatas kepentingan diri dan kelompoknya, meliputi: cinta tanah air, semangat kebangsaan, dan menghargai kebhinekaan

Intergritas ialah upaya seseoramg untuk menjadikan dirinya sebagai seseorang yang selalu dapat dipercaya, baik dalam perkataan, tindakan, dan pekerjaan, meliputi: kejujuran, keteladanaan, kesatuan, dan cinta kepada kebenaraan. (4) Mandiri ialah nilai yang menjadikan seseorang untuk tidak bergantung kepada orang lain, dan berusaha dengan sendirinya dalam mewujudkan cita-cita, mimpi dan harapan, meliputi: kerja keras, kreatif, disiplin, berani, dan pembelajar (5) Gotong royong ialah nilai yang mencerminkan tindakan menghargai semangat kerja sama dan bahu membahu menyelesaikan persoalaan bersama, meliputi: kerjasama, solidaritas, saling menolong, dan kekeluargaan.17

b. Kepuasan pelanggan. Kepuasan pelanggan dalam pembelajaran karakter dapat berupa kepuasan terhadap hasil yang dicapai, seperti: kepuasan orang tua terhadap perubahan sikap/karakter yang dimiliki oleh seorang peserta didik yang diperoleh dari hasil pembelajaran. Untuk mencapai kepuasan pelanggan maka pendidik harus berfokus pada kepuasaan pelanggan baik itu pelanggan eksternal maupun internal. Pelanggan eksternal ialah pelanggan yang menentukan mutu lulusan sedangkan pelanggan internal ialah pelanggan yang menentukan mutu, proses, dan lingkungan yang berhubungan dengan lulusan. ${ }^{18}$

c. Perbaikan terus-menerus. Perbaikan terus-menerus dalam pembelajaran

${ }^{17}$ Ibid.,

18 Imam Machali en Ara Hidayat, The Handbook Of Education Management: Teori dan Praktik Pengelolaan Sekolah/Madrasah di Indonesia, (Jakarta: PRENAMEDIA GROUP, 2016), hlm. 386. 
karakter dimaksudkan untuk meningkatkan mutu capaian dengan cara perbaikan secara terus-menerus dalam pembelajaran, seperti: perbaikan dalam hal penyampaian bahan ajar yaitu dengan menggunakan berbagai macam media yang tepat guna, mengontrol, mempersiapkan, dan memperbaiki lingkungan belajar secara berkala, menjadikan proses pembelajaran menjadi aktif dan menjadi teladan bagi peserta didik dalam pengembangan karakter.

d. Menyeluruh disemua komponen organisasi. Yang dimaksud dengan menyeluruh disemua komponen organisasi ialah perbaikan secara menyeluruh/tidak hanya berfokus pada pembelajaran. Perbaikan secara menyeluruh melibatkan semua komponen organisasi baik dari dalam maupun luar lembaga pendidikan, seperti: adanya perubahan kurikulum dari KTSP menjadi K13, adanya penekanan pada kegiatan intrakurikuler, kokurikuler, dan ekstrakurikuler, perbaikan sarana dan prasarana lembaga pendidikan, dan kebijakan pemerintah terhadap pembangunan karakter.

Pembelajaran karakter merupakan proses rangkaian kegiatan pembelajaran yang berlangsung di dalam maupun di luar kelas yang bertujuan untuk menjadikan peserta didik dapat menguasai kompetensi (materi), mengenal, menyadari/peduli, dan meninternalisasikan nilai-nilai dan menjadikanya perilaku. ${ }^{19}$

Pembelajaran karakter dapat diterapkan oleh seorang guru dalam pembelajaran dengan menggunakan pendekatan Total Quality Management. Adapun hal-hal yang dapat dilakukan guru dalam penanaman nilai-nilai karakter dalam pembelajaran, sebagai berikut:

a. Perencanaan pembelajaran karakter. Perencanaan pembelajaran merupakan suatu kompetensi pedagogik yang wajib dimiliki oleh setiap guru atau tenaga pendidik. Pada tahap perencanaan ini guru menyusun silabus, RPP, dan bahan ajar dimana silabus, RPP, dan bahan ajar tersebut dirancang sedemikian rupa agar muatan kegiatan pembelajaran yang memfasilitasi/berwawasan pendidikan karakter. $^{20}$ Dalam hal ini setidaknya ada tiga komponen modifikasi yang dilakukan agar silabus, RPP, dan bahan ajar memfasilitasi pendidikan karakter. Ketiga komponen tersebut, sebagai berikut: (1) Adanya penambahan dan/atau modifikasi kegiatan pembelajaran sehingga

${ }^{19}$ Endah Sulistyowati, Implementasi Kurikulum Pendidikan Karakter, (Yogyakarta: Citra Aji Parama, 2012), hlm. 127.

20 Siti Zulaikha, "Implementasi Pendidikan Karakter, ..., hlm. 232. 
kegiatan pembelajaran tersebut dapat mengembangkan karakter peserta didik (2) Adanya penambahan dan/atau modifikasi pada indikator pencapaian sehingga indikator tersebut dapat mengukur pencapaian belajar dan karakter peserta didik (3) Adanya penambahan dan/atau modifikasi pada teknik penilaian sehingga teknik penilaian tersebut dapat mengukur perkembangan karakter peserta didik. ${ }^{21}$

b. Pembelajaran karakter berbasis siswa (PBS). Pembelajaran berbasis siswa (PBS) merupakan proses pembelajaran yang ditekankan pada keaktifan siswa yang meliputi aspek kognitif, afektif, dan psikomotorik, dan dalam pembelajaran bersifat student centered. ${ }^{22}$

Dari pengertian diatas maka siswa atau peserta didik dalam pembelajaran karakter harus ditempatkan sebagai faktor utama, yaitu dengan menempatkan siswa dalam proses pembelajaran sebagai subjek belajar yang memiliki potensi, dan proses pembelajaran diarahkan untuk memberikan pengalaman belajar agar siswa dapat mengembangkan seluruh potensi yang dimilikinya.

Pembelajaran karakter berbasis siswa ini dalam tahap pelaksanaanya memiliki beberapa langkah yang meliputi: kegiatan pendahuluan, kegiatan inti (eksplorasi, elaborasi, konfimasi) dan kegiatan penutup.

1) Kegiatan pendahuluan.

Pada kegiatan pendahuluan guru menyiapkan peserta didik secara psikis dan fisik untuk mengikuti proses pembelajaran dengan mengajukan sejumlah pertanyaan yang mengaitkan materi sebelumnya dengan materi yang akan dipelajari, menjelaskan tentang tujuan pembelajaran atau kompetensi dasar yang akan dicapai, dan menyampaikan cakupan materi dan penjelasan uraian kegiatan sesuai dengan silabus. ${ }^{23}$

2) Kegiatan inti (ekplorasi).

Pada kegiatan ekplorasi ini seorang guru melibatkan atau memerintahkan siswa untuk mencari informasi sebanyakbanyaknya, yang sesuai dengan topik yang dipelajari, nilai yang ditamakan berupa (mandiri, berpikir logis, kreatif dan kerjasama). Kemudian guru menggunakan berbagai macam bentuk pendekatan pembelajaran, media pembelajaran, dan sumber belajar lainnya, nilai yang Konsep, ..., hlm. 226.

21 Heri Gunawan, Pendidikan Karakter: Management, ..., hlm. 131.

Zahroh, Total Quality 
diatanamkan yaitu: (kreatif, kerja keras).

Selanjutnya guru memfasilitasi terjadinya interaksi antara peserta didik dengan peserta didik dan peserta didik dengan guru, lingkungan, dan sumber belajar lainya, nilai yang ditanamkan yaitu: (kerja sama, peduli lingkungan, dan saling menghargai). Kemudian dilanjutkan dengan pelibatan peserta didik untuk dapat aktif dalam setiap kegiatan pembelajaran, nilai yang ditanamkan yaitu: rasa percaya diri dan mandiri).

Guru memfasilitasi peserta didik untuk melakukan percobaan dilaboratorium, studio atau lapangan, nilai yang ditanamkan yaitu: (mandiri, kerja sama, kerja keras). ${ }^{24}$

3) Kegiatan inti (elaborasi).

Pada kegiatan elaborasi ini guru membiasakan peserta didik untuk membaca dan menulis melalui tugastugas tertentu yang bermakna, nilai yang ditanamkan yaitu: (cinta ilmu, kreatif, dan logis). Guru memfasilitasi peserta didik melalui pemberian tugas, diskusi, dan lainlain untuk memunculkan gagasan baru baik secara lisan maupun

24 Siti Zulaikha, "Implementasi Pendidikan Karakter, ..., hlm. 234-235. tertulis, nilai yang ditanamkan yaitu: (kreatif, percaya diri, kritis, saling menghargai, santun).

Selanjutnya guru memberi kesempatan kepada peserta didik untuk berpikir, menganalisis, bertindak tanpa rasa takut, dan menyelesaikan masalah, nilai yang ditanamkan yaitu: (kreatif, percaya diri, kritis). Guru memfasilitasi peserta didik dalam pembelajaran kooperatif dan kolaboratif, nilai yang ditanamkan yaitu: (kerja sama, saling menghargai, tanggung jawab).

Kemudian guru memfasilitasi peserta didik agar dapat berkompetisi secara sehat dalam rangka meningkatkan prestasi belajar, nilai yang ditanamkan yaitu: (jujur, disiplin, kerja keras, menghargai). Guru memfasilitasi peserta didik untuk membuat laporan ekplorasi yang berupa laporan lisan maupun tertulis, secara individual maupun kelompok, nilai yang ditanamkan yaitu: (jujur, beratanggung jawab, percaya diri, saling menghargai, mandiri, kerja sama).

Guru memfasilitasi peserta didik dalam penyajian hasil kerja individual ataupun kelompok. Guru memfasilitasi peserta didik dalam melakukan pameran, turnamen, 
festival, serta produk yang dihasilkan. Guru memfasilitasi peserta didik untuk melakukan kegiatan yang dapat menumbuhkan rasa percaya diri dan kebanggaan pada diri peserta didik, nilai yang ditanamkan yaitu: (percaya diri, saling menghargai, mandiri, kerja sama). ${ }^{25}$

4) Kegiatan inti (konfirmasi).

Pada kegiatan konfirmasi ini guru memberikan umpan balik positif dan penguatan dalam bentuk lisan, tulisan, isyarat, maupun hadiah terhadap keberhasilan peserta didik, nilai yang ditanamkan yaitu: (saling menghargai, percaya diri, santun, kritis, logis).Guru memberikan konfirmasi terhadap hasil ekplorasi dan elaborasi peserta didik dari berbagai sumber, nilai yang ditanamkan yaitu: (percaya diri, logis, kritis).

Selanjutnya guru memfasilitasi peserta didik untuk melakukan refleksi guna memperoleh pengalaman dari pembelajaran yang telah dilakukan, nilai yang ditanamkan yaitu: (memahami kelebihan dan kekurangan diri sendiri). Guru memfasilitasi peserta didik agar dapat lebih

25 Heri Gunawan, Pendidikan Karakter: Konsep, ..., hlm. 232. jauh/dalam/luas dalam hal pengkajian dan pemrolehan pengetahuan, keterampilan, dan sikap, nilai yang ditanamkan yaitu: (peduli, santun, cinta ilmu, percaya diri). ${ }^{26}$

5) Kegiatan penutup.

Pada kegiatan penutup ini guru bersama peserta didik atau secara sendiri membuat sebuah simpulan dari pembelajaran yang dilakukan, nilai yang ditanamkan yaitu: (mandiri, kerjasama, kritis, logis). Guru melakukan penilaian atau refleksi terhadap kegiatan yang telah dilakukansecara konsisten dan terprogram, nilai yang ditanamkan yaitu: (jujur, mengetahui kekurangan dan kelebihan).

Selanjutnya guru memberikan feedback (umpan balik) kepada peserta didik mengenai proses dan hasil pembelajaran yang telah dilakukan, nilai yang ditanamkan yaitu: (saling menghargai, percaya diri, santun, kritis, logis). Kemudian guru merencanakan sebuah kegiatan tindak lanjut yang berupa pembelajaran remedi, program pengayaan, layanan koseling atau memberikan tugas secara individual ataupun kelompok sesuai dengan hasil belajar yang diperoleh peserta

${ }^{26}$ Ibid, hlm. 233. 
didik, serta guru menyampaikan rencana pembelajaran yang akan dilakukan pada pertemuan berikutnya. $^{27}$

c. Evaluasi pembelajaran karakter

Evaluasi pembelajaran merupakan kegiatan yang dilakukan untuk mengetahui perubahan perilaku dan pembentukan kompetensi pada peserta didik. Evaluasi pembelajaran ini dapat berupa: penilaian kelas, tes kemampuan dasar, penilaian akhir satuan pendidikan dan sertifikasi benchmarking serta penilaian program. ${ }^{28}$

Evaluasi pembelajaran sebaiknya dilakukan tidak hanya untuk mengukur pencapaian akademik tetapi juga keperibadian siswa atau peserta didik. Diantara teknik-teknik yang dapat dilakukan untuk penilaian akademik maupun keperibadian siswa atau peserta didik, sebagai berikut: (1) Observasi (dengan lembar obserbasi/pengamatan) (2) Penilaian diri (dengan lembar penilaian diri/kuisioner (3) Penilaian antar teman (lembar penilaian antar teman. $^{29}$

Pada akhirnya penerapan Total Quality Management dalam pembelajaran karakter bertumpu pada proses dimana

${ }^{27}$ Ibid, hlm. 233-234.

28 E. Mulyasa, Standar Kompetensi dan Sertifikasi Guru, (Bandung: Remaja Rosdakarya, 2007), hlm. 108

29 Heri Gunawan, Pendidikan Karakter: Konsep, ..., hlm. 235. dalam proses pembelajaran dibutuhkan komitmen dan perbaikan terus menerus baik pada proses, lingkungan sekitar, pribadi guru dll, yang mendukung dalam penanaman dan pembentukan karakter peserta didik.

Aminatul Zahroh dalam Total Quality Management: Teori dan Prakttik Manajemen untuk Mendongkrak Mutu Pendidikan, mengatakan bahwa Total Quality Management dalam penerapannya pada pembelajaran memiliki beberapa indikator yang perlu dimonitori, yaitu: segi orang tua, siswa, dan guru-guru di sekolah. Indikator dari segi orang tua dapat berupa kegiatan membaca dan belajar setiap hari, dan dukungan terhadap pekerjaan rumah anak. Indikator dari segi siswa dapat berupa penguasaan informasi baru tentang dasar bidang pelajaran, informasi baru tentang kebiasaan belajar. Dan indikator dari segi guru yaitu: guru memperoleh atau memiliki informasi baru tentang potensi pelajar, motivasi, tujuan, akses terhadap informasi dan kemajuan pelajar. $^{30}$

\section{METODE PENELTIAN}

Penelitian ini adalah penelitian lapangan (field research) yang bercirikan kualitatif deskriftif. Kualitatif deskriptif merupakan penelitian yang dilakukan untuk menggambarkan secara sistematis faktafakta atau karateristik dari populasi tertentu, atau bidang tertentu, baik berupa keadaan,

\footnotetext{
Management, ..., hlm. 145-146.
} 
permasalahan, sikap, pendapat, kondisi, prosedur, atau sistem secara faktual dan cermat. $^{31}$

Penelitian ini difokuskan kepada kajian mengenai implementasi manajemen pembelajaran karakter berbasis Total Quality Management di SMP Muhammadiyah 3 Yogyakarta, dengan menggunakan metode observasi, dokumentasi, dan wawancara sebagai alat pengumpulan datanya.

Adapun yang menjadi sumber dan data dalam penelitian ini yaitu kepala sekolah, waka humas, tenaga pendidik, siswa-siswi SMP Muhammadiyah 3 Yogyakarta dan segala yang terkait dengan kajian penelitian. Pada penelitian ini digunakan metode analisis deskriptif yaitu sebuah metode yang menjelaskan secara sistematis materi-materi pembahasan yang berasal dari berbagai sumber untuk kemudian dilakukan analisis guna memperoleh hasil atau kesimpulan akhir yang valid. Penelitian ini dalam analisis datanya menggunakan analisis data dari Miles dan Huberman yang meliputi: (1) Reduksi data (2) Penyajian data, dan (3) Gambar kesimpulan atau verifikasi. ${ }^{32}$

\section{HASIL DAN PEMBAHASAN}

1. Implementasi Manajemen Pembelajaran Karakter Berbasis Total Quality

${ }^{31}$ Soewadji Jusuf, Pengantar Metodologi Penelitian, (Jakarta: Mitra Wacana Media, 2012), hlm. 26.

32 Sugiyono, Metode Penelitian Pendidikan: Pendekatan Kuantitatif, Kualitatif, dan R\&D, (Bandung: Alfabeta, 2013), hlm. 337.
Management di SMP Muhammadiyah 3 Yogyakarta.

SMP Muhammadiyah 3 Yogyakarta merupakan salah satu sekolah menengah atas yang dimiliki Muhammadiyah di Yogyakarta. SMP Muhammadiyah 3 Yogyakarta dikelola oleh ibu Heriyati, S.Pd.,MM selaku kepala sekolah dan memiliki visi "terwujudnya siswa beriman, unggul dalam prestasi dan berwawasan lingkungan". 33 Ditangan ibu Heriyati, S.Pd.,MM SMP Muhammadiyah 3 Yogyakarta mengalami perkembangan yang begitu baik khususnya dalam pembentukan karakter peserta didik sehingga tak jarang SMP Muhammadiyah 3 Yogyakarta mendapat juara dalam berbagai ajang perlombaan baik tingkat provinsi maupun nasional.

Pembelajaran karakter berbasis Total Quality Management merupakan sebuah pembelajaran untuk menanamkan nilai-nilai karakter (relegius, nasionalis, intergritas, mandiri, dan gotong royong) dengan menggunakan konsep Total Quality Management, yaitu: quality, kepuasan pelanggan, perbaikan terus-menerus, dan menyeluruh disemua komponen organisasi.

\footnotetext{
Hasil Dokumentasi SMP Muhammadiyah 3 Yogyakarta pada tanggal 02 November 2018
} 
a. Quality.

Quality dalam pembelajaran karakter di SMP Muhammadiyah 3 Yogyakarta terwujud dalam bentuk penanaman karakter (relegius, nasionalis, intergritas, mandiri, dan gotong royong) melalui kegiatankegiatan yang dilakukan sekolah sehingga berpengaruh terhadap quality atau output, outcome pada diri peserta didik. Berikut nilai-nilai karakter yang ditanamkan melalui kegiatan sekolah di SMP Muhammadiyah 3 Yogyakarta:

1) Relegius.

Nilai relegius ini terwujud dalam kegiatan, sebagai berikut: (1) Tadarus bersama dipagi hari tepatnya sepuluh menit sebelum proses pembelajaran dimulai (2) Sholat dhuha, zuhur, dan ashar berjamaah disekolah (3) Dzikir, do'a dan kultum yang dilakukan setelah sholat berjama'ah (4) pembinaan membaca alquran dengan fasih, dan (5) hafalan juz 30 dan ayat-ayat alquran pilihan. $^{34}$

2) Nasionalis.

Nilai nasionalis ini terwujud dalam bentuk upacara sekolah dimana pimpinan /

34 Hasil Observasi di SMP Muhammadiyah 3 Yogyakarta pada tanggal 02 November 2018 kepala sekolah, guru, staff, dan peserta didik berkumpul bersama dalam melaksanakan upacara sekolah, megingat dan menghormati nilai-nilai perjuangan para leluhur. Hal ini merupakan bentuk dari cinta tanah air, semangat kebangsaan, dan menghargai kebangsaan. Selain itu semua elemen sekolah (kepala sekolah, guru, peserta didik, dan lingkungan sekolah) wajib saling menghargai dan menjunjung tinggi nilai-nilai keragamaan. Nilai nasionalis di SMP Muhammadiyah 3 Yogyakarta ditanamkan juga melalui berbagai macama kegiatan ekstrakurikuler yang digalangkan, seperti: PMR (palang merah remaja), Paskibraka, Pramuka, KIR (karya ilmiah remaja), dan lain-lain. ${ }^{35}$

3) intergritas.

Nilai intergritas ini terwujud dalam bentuk keteladanan yang diberikan seorang guru terhadap peserta didiknya untuk di tiru. Bentuk keteladanan yang dilakukan ialah dengan berusaha untuk tidak terlambat sholat, sehingga siswa juga akan membiasakan diri

35 Hasil Observasi di SMP Muhammadiyah 3 Yogyakarta pada tanggal 05 November 2018 
untuk tidak terlambat sholat. $\mathrm{Hal}$ ini seperti yang dikemukakan oleh guru A yang mengatakan bahwa "saya memberikan contoh untuk sholat tepat waktu, jadi secara perlahan mereka akan ikut mencontoh yang saya lakukan".36

Selain dalam hal sholat keteladanan juga terwujud ketika datang kesekolah tepat waktu atau tidak terlambat. Dalam hal ini guru-guru dituntut untuk datang lebih awal dan tidak terlambat kesekolah. Jika ada guru atau staf yang terlambat datang kesekolah maka akan dikenakan sanksi berupa teguran hingga diberikanya surat peringatan. Begitu pun sebaliknya terhadap peserta didik. Peserta didik yang terlambat datang kesekolah akan diberikan sanksi dan perlakuan yang berbeda, seperti: membaca alquran hingga dipanggil orang tuanya untuk menghadap pihak sekolah.

SMP Muhammadiyah 3 Yogyakarta, selain menerapkan nilai-nilai keteladanan juga menerapkan nilai kesantunan. Hal ini terwujud dalam kegiatan

36 Hasil Wawancara dengan guru A pada tanggal 06 November 2018 sekolah yang berupa 3S (salam, sapa, dan senyum) yang dilakukan ketika pagi dan sore hari / siswa pulang sekolah. Kegiatan 3S ini diawali dipagi hari yaitu ketika siswa masuk sekolah dimana para siswa dan guru akan berinteraksi saling memberikan senyuman, sapa, dan bersalaman. Kegiatan ini juga memudahkan guru untuk melakukan pengecekan terhadap kerapian dan kelengkapan dari cara berpakaian siswa. Hal ini sebagaimana yang dinyatakan oleh guru B, bahwa "kita menerapkan budaya 3S itu sejak pagi ketika anak-anak masuk sekolah sampai mereka pulang". 37

4) Mandiri.

Nilai mandiri di SMP Muhammadiyah 3 Yogyakarta ini terwujud dalam bentuk kerja keras dan disiplin. Dimana guruguru di SMP Muhammadiyah 3 Yogyakarta ini tidak selalu bergantung kepada pimpinan / kepala sekolahnya, contohnya: pada saat kepala sekolah tidak berada disekolah, guru-guru berserta staff tetap menajalankan tugas-tugas mereka

37 Hasil Wawancara dengan guru B pada tanggal 06 November 2018 
sebagaiamana yang ditugaskan tanpa perlu pengawasan.

Selain itu untuk disiplin yang dilakukan oleh setiap pelaku di SMP Muhammadiyah 3 Yogyakarta sudah berjalan dengan baik, sebagai contoh: setiap peserta didik diwajibkan untuk membersihkan kelas sebelum memulai pembelajaran. Hal ini dipertegas dengan pernyataan waka kesiswaan SMP Muhammadiyah 3 Yogyakarta, bahwa "siswa yang memiliki jadwal piket akan datang kesekolah lebih awal". ${ }^{38}$

5) Gotong royong.

Nilai gotong royong di SMP Muhammadiyah 3 Yogyakarta terwujud dalam bentuk kerja sama yang dilakukan oleh pimpinan dengan para guru dan staff, guru dengan guru, guru dengan peserta didik, dan pihak sekolah dengan wali / orang tua peserta didik. Kerjasama ini dilakukan untuk pencapaian dari visi / tujuan dari SMP Muhammadiyah 3 Yogyakarta. Sebagai contoh: kerja sama dalam menangani masalah siswa disekolah.

${ }^{38}$ Hasil Wawancara dengan waka kesiswaan SMP Muhammadiyah 3 Yogyakarta pada tanggal 06 November 2018
Selain hal diatas nilai gotong royong juga terwujud dalam bentuk kekeluargaan, sebagai contoh: ketika ada salah satu siswa yang sakit maka guru kelas bersama siswa lainya akan berkunjung / menjenguk siswa yang sakit tersebut. Hal ini dilakukan agar siswa saling saling mendukung, memberi semangat, dan motivasi.

b. Kepuasan pelanggan.

SMP Muhammadiyah 3 Yogyakarta memberikan kepuasaan pelanggan dalam bentuk pelayananpelayanan yang diberikan pihak sekolah terhadap peserta didik. Pelayanan-pelayanan tersebut dapat berupa, pelayanan sarana prasarana, media pembelajaran, kegiatan intrakurikuler, ekstrakurikuler dan lain sebagainya yang mendukung dari telaksananya pembelajaran karater. Contohnya dalam hal sarana prasarana, seperti adanya dua perpusatakaan, dua lab bahasa, dua lab komputer, satu lab IPA, satu multimedia, dua tempat ibadah, tiga kantin, dua ruang bimbingan konseling, $24 \mathrm{KM} / \mathrm{WC}$ peserta didik dan lain sebagainya.

Selain itu

SMP

Muhammadiyah 3 Yogyakarta memiliki beberapa keunggulan 
dibandingkan dengan sekolah lainya, seperti: adanya PTD (Pendidikan tekhnologi Dasar) / BTE (Basic Technology Education) / Prakarya, Kelas IT, dan kelas bilingual. Dan dalam kegiatan ekstrakurikuler SMP Muhammadiyah 3 Yogyakarta menggalangkan beberapa kegiatan ekstrakurikuler, sebagai berikut: (1) Kegiatan yang bersifat religi, yaitu: qiro'ah atau membaca al-qur'an.(2) Kegiatan yang bersifat seni yaitu: Music, Teater, Paduan Suara, Band, Karawitan, Modeling, Fotografi dan Sinematografi serta Paduan suara. (3) Kegiatan yang bersifat pengetahuan yaitu: Bahasa Inggris, Palang Merah Indonesia (PMI), Karya Ilmiah Remaja (KIR). (4) Kegiatan yang bersifat teknologi yaitu: Robotic dan desain grafis (5) Kegiatan yang bersifat olah raga, diantaranya: Futsal, Bola basket, Badminton, Tapak Suci dan Hizbul Wathan.

Pelayanan-pelayanan yang diberikan SMP Muhammadiyah 3 Yogyakarta telah cukup baik dan telah berhasil memuaskan pelanggan hal ini dapat dilihat dari sejumlah prestasi dan output yang diperpoleh peserta didik, seperti dalam hal prestasi SMP Muhammadiyah 3 Yogyakarta telah mendapatkan berbagai penghargaan. Contoh: Juara
II Qiro'ah Provinsi 2015, Juara I Internasional Robotic (Islamic School Robotic Olympicad) 2013, Juara I Provinsi Blog Go Green 2013, Juara I Nasional Robotic 2013. ${ }^{39}$ Sedangkan dalam hal Output peserta didik telah menerapkan berbagai nilai-nilai karakter dalam kehidupan seharihari, seperti: melaksanakan sholat lima waktu dalam sehari.

c. Perbaikan terus menerus dan menyeluruh disemua komponen organisasi.

Perbaikan terus menerus dan meyeluruh disemua komponen organisasi adalah perbaikan yang tidak hanya dilakukan disekolah melaikan diseluruh komponen organisasi yang terbuhung seperti: kebijakan pemerintah, kurikulum, sekolah, sarana prasarana dll secara berkelanjutan / terus menerus.

$\begin{array}{lr}\text { Perbaikan } & \text { terus } \\ \text { menerus di } & \text { SMP } \\ \text { Muhammadiyah } & 3\end{array}$
Yogyakarta ini dapat dilihat dari perbaikan yang selalu dilakukan pihak sekolah dalam tiap tahunnya. Sebagai contoh perbaikan dalam 
bidang kurikulum. Beberapa tahun yang lalu SMP

Muhammadiyah

Yogyakarta

masih

menggunakan kurikulum

KTSP tapi saat ini SMP

Muhammadiyah

Yogyakarta

telah

menggunakan Kurikulum

2013 dengan pembelajaran

Full Day School selama lima

hari pagi hingga sore.

Selain itu dalam hal luas wilayah, pada tahun 1951 SMP Muhammadiyah 3 Yogyakarta hanya memiliki luas tanah seluas $1183 \mathrm{~m}^{3}$. Kemudian pada tahun 1985 memperluas area tanah kearah timur seluas $350 \mathrm{~m}^{3}$ dan dibangunlah enam ruang kelas dengan konsep bertingkat begitu seterusnya SMP Muhammadiyah 3 Yogyakarta selalu mengalami perkembangan hingga pada masa ibu Heriyati, S.Pd.,MM pada tahun 2006 hingga sekarang, telah dilakukan pembangunan lantai 3 di kampus 1 untuk mushola, aula, laboratorium IPA, dan lapangan olahraga dikampus 3.

Begitupun dalam hal sarana prasarana pembelajaran, SMP Muhammadiyah 3 Yogyakarta memberikan sarana prasarana pembelajaran yang cukup baik seperti ruang kelas yang banyak, perpustakaan, multimedia dll. Selain itu dalam hal kerjasama SMP Muhammadiyah 3 Yogyakarta telah melakukan kerjasama luar negeri dengan (Sister School) dengan Satri Si Suriyothai School Bangkok-Thailand, ABIM (Angkatan Belia Islam Malaysia), Madrasah Islamiyah AlJuneid Singapura, Hwabuk Elementary School Jeju-Korea Selatan dan Obyun Middle School Jeju-Korea Selatan. ${ }^{40}$ Semua hal ini dilakukan dalam rangka perbaikan terus menurus dan peningikatan kualitas dari SMP Muhammadiyah 3 Yogyakarta.

Pembelajaran karakter berbasis Total Quality Management selain diterapkan seperti yang telah dijelaskan sebelumnya, diterapkan juga dalam bentuk proses pembelajaran. Terdapat empat hal yang dapat dilakukan oleh guru dalam penanaman nilai-nilai karakter, sebagai berikut: (1) Perencanaan pembelajaran karakter (2) Pembelajaran karakter berbasis siswa (3) Evaluasi pembelajaran karakter. Berikut hasil penjelasan mengenai penanaman nilai-nilai karakter pada proses pembelajaran di SMP Muhammadiyah 3 Yogyakarta, yang penulis proleh dari hasil wawancara dengan guru Pendidikan Agama Islam SMP Muhammadiyah Yogyakarta:

${ }^{40}$ Hasil Dokumentasi SMP Muhammadiyah 3 Yogyakarta pada tanggal 02 November 2018 
a. Perencaan pembelajaran karakter.

Pada tahap ini guru di SMP Muhammadiyah 3 Yogyakarta telah melakukan desain RPP sedemikian rupa sehingga nilai-nilai yang akan mereka tanamkan pada proses pembelajaran dapat tersampaikan. Namun yang menjadi kendala ialah ada beberapa guru-guru yang terkadang ketika mengajar tidak mengikuti RPP seperti yang ia desain sebelumnya. Hal ini dipertegas dengan pernyataan guru A, bahwa "terkadang saya mengajar tidak mengikuti RPP yang saya buat, tapi tidak juga saya melenceng jauh dari RPP yang saya buat, ya itu disebabkan lingkungan kelas yang berubah-ubah jadi kita meyesuaikan dengan menggunakan caracara tertentu". 41

b. Pembelajaran karakter berbasis siswa.

SMP Muhammadiyah 3 Yogyakarta telah menerapkan pembelajaran karakter berbasis siswa hal ini dikarenakan SMP Muhammadiyah 3 Yogyakarta itu sendiri telah menerapkan kurikulum 2013, dimana pada kurikulum 2013 proses pembelajaran terpusat pada peserta didik atau student center, sehingga peserta didik dituntut untuk aktif dan kreatif pada proses pembelajaran.

Pada pembelajaran karakter berbasis siswa ini guru SMP Muhammadiyah 3 Yogyakarta telah

${ }^{41}$ Hasil Wawancara dengan guru A pada tanggal 06 November 2018 melakukan beberapa langkah-langkah kegiatan pembelajaran, seperti: kegiatan pendahuluan, kegiatan ini (eksplorasi, elaborasi, konfirmasi, dan penutup) hal ini juga termasuk dalam RPP kurikulum 2013. Selain itu guru-guru juga telah menggunakan berbagai metode mengajar (demostrasi, diskusi dll) dan memanfaatkan berbagai media pembelajaran (media gambar, multimedia (film, video, audio), laptop, dll). Hal ini dipertegas dengan pernyataan guru A bahwa "saya biasanya memakai gambar-gambar atau poster untuk memperjelas penjelasan saya, biasanya ini saya pakai sewaktu mengajar tata cara sholat atau wudhu. Kalau untuk metode, biasanya saya memakai metode ceramah, tapi beberapa kali juga kita menggunakan demostrasi, saya contohkan sewaktu anak-anak belajar berwudhu dan sholat". 42

c. Evaluasi pembelajaran karakter.

Evaluasi pembelajaran karakter di SMP Muhammadiyah 3 Yogyakarta tidak hanya dilakukan pada akhir semester. Namun evaluasi pembelajaran karakter dilakukan pada tiap minggu atau bulan hal ini tergantung pada guru yang mengajar. Namun untuk evaluasi secara keseluruhan biasanya dilakukan pada akhir semester yang dapat berupa, penilaian rapor, rapat mengenai

42 Hasil Wawancara dengan guru A pada tanggal 06 November 2018 
pembelajaran / kendala-kendala pembelajaran selama satu semester dll.

Berdasarkan beberapa data yang telah dipaparkan diatas maka penulis dapat menganalisis mengenai implementasi manajemen pembelajaran karakter berbasis Total Quality Management di SMP Muhammadiyah 3 Yogyakarta, dengan hasil sebagai berikut:

1. SMP Muhammadiyah 3 Yogyakarta telah mengimplementasikan beberapa nilainilai karakter melalui kegiatan-kegiatan sekolah. Sebagai contoh: nilai relegius yang diterapkan melalui program tadarus pagi, sholat dhuha, zuhur, ashar dll. Nilai nasionalis yang terwujud dan diterapkan dalam upacara bendera dan kegiatan ekstrakurikuler (Paskibra, PMR, Pramuka dll). Nilai intergitas yang terwujud dan diterapkan dalam bentuk keteladanan dan kegiatan 3S (salam, senyum, sapa). Nilai mandiri yang terwujud dan diterapkan dalam usaha kerja keras dan disiplin. Nilai gotong royong yang terwujud dan diterapkan dalam bentuk kerjasama antara pimpinan dengan guru / staff, guru dengan guru, guru dan peserta didik, dan pihak sekolah dengan orang tua, dan dalam bentuk kekeluargaan (menjenguk rekan / peserta didik yang sakit).

2. SMP Muhammadiyah 3 Yogyakarta sedikit banyak telah mengimplementasikan konsep-konsep
Total Quality Management dalam pembelajaran karakternya. Sebagai contoh: adanya quality (peserta didik) yang di bentuk melalui pelayananpelayanan dan kegiatan-kegiatan yang dilakukan sekolah. Adanya kepuasan pelanggan yakni berupa output (peserta didik) yang meraih prestasi-prestasi gemilang, dan dapat melaksanakan sholat lima waktu dikehidupan seharihari. Adanya perbaikan terus menerus dan menyeluruh disemua komponen organisasi yakni berupa penggunaan kurikulum 2013, melakukan kerjasama luar negeri, dan melakukan perbaikan sarana prasarana pendidikan.

3. SMP Muhammadiyah 3 Yogyakarta telah menerapkan kurikulum 2013 dan dalam proses pembelajaran karakter berbasis Total Quality Management telah menerapkan pembelajaran sesuai dengan langkah-langkah pembelajaran (kegiatan pendahuluan, inti dan evaluasi pembelajaran) namun dalam hal ini masih sangat membutuhkan perbaikan yang bersifat terus menerus. Sebagai contoh: masih adanya beberapa guru yang terkadang tidak mengikuti RPP dalam melakukan pembelajaran. 


\section{KESIMPULAN}

Pembelajaran karakter dapat diterapkan dengan menggunakan konsep Total Quality Management, yaitu: quality, kepuasaan pelanggan, perbaikan terus menerus, dan menyeluruh disemua komponen organisasi. Selain itu pembelajaran karakter dapat juga diterpakan dalam bentuk proses pembelajaran dikelas yakni dengan menerapkan langkah-langkah pembelajaran (kegiatan pendahuluan, kegiatan inti, dan evaluasi pembelajaran karakter.

Berdasarkan data dan hasil ulasan yang telah dipaparkan sebelumnya mengenai implementasi manajemen pembelajaran karakter berbasis Total Quality Management di SMP Muhammadiyah 3 Yogyakarta, maka penulis menemukan hal-hal sebagai berikut: (1) SMP Muhammadiyah 3 Yogyakarta telah menanamkan atau mengimplementasikan nilai-nilai karakter (religius, nasionalis, intergritas, mandiri, dan gotong royong) melalui kegiatan-kegiatan sekolah (2) SMP Muhammadiyah 3 Yogyakarta telah mengimplementasikan konsep Total Quality Management dalam pembelajaran karakter (3) SMP Muhammadiyah 3 Yogyakarta telah menerapkan kurikulum 2013 dan dalam proses pembelajaran karakter berbasis Total Quality Management telah menerapkan pembelajaran sesuai dengan langkah-langkah pembelajaran, meskipun pada dasarnya masih banyak membutuhkan perbaikan secara terus menerus.

\section{DAFTAR PUSTAKA}

Gunawan, Heri, Pendidikan Karakter: Konsep dan Implementasi, Bandung: Alfabeta, 2012.

Hendriana, Evinna Cinda en Jacobus, Arnold, "Implementasi Pendidikan Karakter di Sekolah Melalui Keteladanan dan Pembahasan", Jurnal Pendidikan Dasar Indonesia, Vol. 1, No. 2, (2016).

Jusuf, Soewadji, Pengantar Metodologi Penelitian, Jakarta: Mitra Wacana Media, 2012.

Kementerian Pendidikan dan Kebudayaan Republik Indonesia, Gerakan Penguatan Pendidikan Karakter (PPK),cerdasberkarakter.kemendik bud.go.id.

Machali, Imam en Hidayat, Ara, The Handbook Of Education Management:

Teori dan Praktik Pengelolaan

Sekolah/Madrasah di Indonesia, Jakarta: PRENAMEDIA GROUP, 2016.

Marzuki, "Pengintergrasian Pendidikan Karakter dalam Pembelajaran di Sekolah", Jurnal Pendidikan Karakter, Vol. II, No. 1, (2012).

Megawangi, Ratna, Pendidikan Karakter Solusi yang Tepat untuk Membangun

Bangsa, Bogor: Indonesia Heritage Foundation, 2007.

Mulyasa, E, Standar Kompetensi dan Sertifikasi Guru, Bandung: Remaja Rosdakarya, 2007.

Peraturan Menteri Pendidikan dan Kebudayaan Republik Indonesia Nomor 20 Tahun 2018 tentang Penguatan Pendidikan Karakter. 
Salim, Moh Haitami, Pendidikan

Karakter: Konsepsi dan

Implementasinya Secara Terpadu di

Lingkungan Keluarga, Sekolah, Perguruan

Tinggi, dan Masyarakat, Yogyakarta: AR-

RUZZ MEDIA, 2016.

Satriawan, Bismar Harris, Total Quality

Management (TQM): Analisis Akar

Masalah Penerapan Teknologi

Informasi dan Komunikasi (TIK) di

Kabupaten Purbalingga, Yogyakarta:

Tata Kelola Sektor Publik MIP-UMY.

Sugiyono, Metode Penelitian Pendidikan: Pendekatan Kuantitatif, Kualitatif, dan R\&D, Bandung: Alfabeta, 2010.

Sulistyowati, Endah, Implementasi

Kurikulum Pendidikan Karakter.

Yogyakarta: Citra Aji Parama, 2012.

Supriyanto, Achmad, "Implementasi Total Quality Management dalam Sistem Manajemen Mutu Pembelajaran di Institusi Pendidikan", FIP Universitas Malang.

Tafsir, Ahmad, Pendidikan Budi Pekerti, Bandung: Maestro, 2009.

Zahroh, Aminatul, Total Quality Management: Teori dan Prakttik Manajemen untuk Mendongkrak. Mutu Pendidikan, Yogyakarta: AR-

RUZZ Media, 2016.

Zulaikha, Siti, "Implementasi Pendidikan Karakter dalam Pembelajaran", Jurnal Dinamika Ilmu, Vol. 14,No.

2, (2014).

https://indonesiabaik.id/infografis

kegiatan-pendidikan-karakter.html

http://kumpulanmakalahkuliahlengkap.blo gspot.com/2017/03/konsep-fitrahmanusia.html 